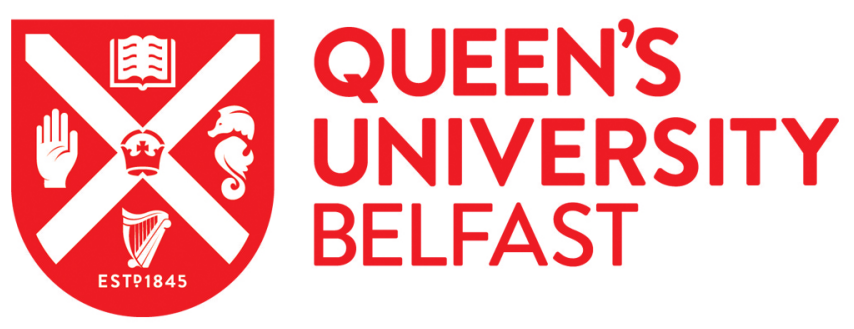

\title{
Radiotherapy and Immunotherapy Combinations in Non-small Cell Lung Cancer: A Promising Future?
}

Hanna, G. G., \& Illidge, T. (2016). Radiotherapy and Immunotherapy Combinations in Non-small Cell Lung Cancer: A Promising Future? Clinical oncology (Royal College of Radiologists (Great Britain)), 28(11), 726-731. https://doi.org/10.1016/j.clon.2016.07.014

\section{Published in:}

Clinical oncology (Royal College of Radiologists (Great Britain))

\section{Document Version:}

Peer reviewed version

Queen's University Belfast - Research Portal:

Link to publication record in Queen's University Belfast Research Portal

\author{
Publisher rights \\ ( 2016 The Royal College of Radiologists. Published by Elsevier Ltd. All rights reserved. This manuscript version is made available under \\ the CC-BY-NC-ND 4.0 license http://creativecommons.org/licenses/by-nc-nd/4.0/, which permits distribution and reproduction for non- \\ commercial purposes, provided the author and source are cited.
}

\section{General rights}

Copyright for the publications made accessible via the Queen's University Belfast Research Portal is retained by the author(s) and / or other copyright owners and it is a condition of accessing these publications that users recognise and abide by the legal requirements associated with these rights.

Take down policy

The Research Portal is Queen's institutional repository that provides access to Queen's research output. Every effort has been made to ensure that content in the Research Portal does not infringe any person's rights, or applicable UK laws. If you discover content in the Research Portal that you believe breaches copyright or violates any law, please contact openaccess@qub.ac.uk. 


\section{Radiotherapy and immunotherapy combinations in NSCLC: a promising future?}

\section{Authors:}

Gerard G. Hanna ${ }^{1}$ and Tim Illidge ${ }^{2}$

\section{Affiliations:}

1.) Centre for Cancer Research and Cell Biology, Queen's University of Belfast, BT9 7AE.

2.) Institute of Cancer Sciences, Manchester Cancer Research Centre, Manchester Academic Health Sciences Centre, University of Manchester, The Christie Hospital, Manchester M20 4BX.

\section{Corresponding Author:}

Dr Gerard Hanna

Centre for Cancer Research and Cell Biology, Queen's University of Belfast, 95 Lisburn Road, Belfast, BT9 7AE.

Email: g.hanna@qub.ac.uk

Keywords: Radiotherapy; Immunotherapy; Checkpoint inhibition; NSCLC;

\section{Conflict of Interest statement:}

The authors have no relevant conflict of interest to report.

$\begin{array}{ll}\text { Word Count: } & 2403 \\ \text { Number of tables: } & 1 \\ \text { Number of figures: } & 0\end{array}$

\section{Abstract.}

Abstract: The goal of re-programming the host immune system to target malignancy with durable antitumour clinical responses has been speculated for decades. In the last decade such speculation has been transformed into reality with unprecedented and durable responses to immune checkpoint inhibitors seen in solid tumours. This mini-review considers the mechanism of action of immune modulating agents and the potential for combination with radiotherapy in the treatment of non-small cell lung cancer. 


\section{Introduction.}

The goal of re-programming the host immune system to target malignancy with durable anti-tumour clinical responses has been speculated for decades [1]. However only over the last decade, has the use of immune modulating agents delivered meaningful clinical responses that has led to great promise in the treatment of lung cancer as well as other solid malignancies [2]. This mini-review outlines the mechanism of action of immune modulating agents and the potential for combination with radiotherapy in the treatment of non-small cell lung cancer (NSCLC).

\section{Immunotherapy in Lung Cancer.}

Immunotherapeutic strategies can be broadly considered as either passive or active. Passive approaches delivered the initial major clinical advances with the introduction of the anti-CD20 monoclonal antibody (mAb) Rituximab which was the first mAb licensed in the treatment of cancer in 1997 followed closely by Trastuzumab with targets and binds to the extra-cellular domain of the HER$2 /$ neu receptor which interferes with receptor function and expression $[2,3]$. Active immunotherapy approaches include non-specific immune modulation (use of interleukin and interferon), therapeutic vaccines (e.g. MAGE-A3 vaccine), modulation of T-cell function and oncolytic viruses and have been slower to demonstrate clinical efficacy [4-6]. However, it is the modulation of T-cell function with the immune checkpoint inhibitors which modulate the anti-CTL antigen-4 (CTLA-4) and the antiprogrammed death-1 (PD-1) ligand function which has particularly attracted interest over the last 5 years with durable clinical responses being seen in malignant melanoma, renal cell carcinoma and non-small cell lung cancer, amongst other tumour types [7].

For many years it has been known that tumours can evade and escape the immune system by a range of immune effectors cells such as T regulatory cells, myeloid deprived suppressor cells (MDSC), tumour associated macrophages (TAM) and via the production of a range of immunosuppressive cytokines (e.g. IL-10, TGF-beta, PGE2 and interferon-y (IFN-y)) within the tumour microenvironment which lead 
to suboptimal priming of dendritic cells and a tolerogenic phenotype [8-10]. A key mechanism of immune evasion is known to be the direct inhibition of cytotoxic T-cells. T-cell activation is a two-step process with the first being antigen recognition by the T-cell receptor and the second the generation of an antigen-independent co-regulatory signal that determines whether the T-cell will be switched on or off in response to the antigen. This second step is overseen by the immune checkpoint pathways, which are either stimulatory or inhibitory. More recently these biological insights about the nature of immune checkpoint inhibitors have led to an increasing number of therapeutics with an intense focus on the PD-1-PD-L1 axis (Programmed Death 1). PD-1 is an inhibitory receptor expressed on T-cells is key to preventing the development of autoimmune disease and it is thought that the function of PD1 is to limit normal tissue damage in the presence of inflammation [11,12]. PD-L1 and PD-L2 are ligands of PD-1 (PD-L1 and PD-L2) and these bind to PD-1 to inhibit T-cell function. Upregulation of PD-L1 and PD-L2 is common in many tumour types and is associated with a poorer prognosis [13]. A number of PD-L1 and PD-L2 inhibitors have been shown to be effective across a range of tumour sites [14]. Two agents, Pembrolizumab and Nivolumab have been shown in randomised trials to be superior to chemotherapy in the second line treatment of NSCLC [15-17]. In a randomised study comparing Docetaxol versus Pembrolizumab as second line therapy in patients with advanced NSCLC who expressed PD-1, those who received Pembrolizumab $10 \mathrm{mg} / \mathrm{kg}$ had median overall survival of 17.3 months as compared to 8.2 months with docetaxel $(p<0 \cdot 0001)$ [15]. Similarly in a study comparing Nivolumab versus Docetaxel in second line non-squamous NSCLC, those who received Nivolumab had a 1 year survival of 19 months compared to 8 months for those received in Docetaxol [17]. Also, importantly in the setting of second line treatment for NSCLC, this increase in survival did not come at the expense of increased toxicity in these studies. For example in the study of Nivolumab versus docetaxel in non-squamous NSCLC, treatment-related adverse events of grade 3 or 4 were seen in $10 \%$ of those treated with Nivolumab, as compared with $54 \%$ of those treated with docetaxel [17]. The results from checkpoint inhibition in NSCLC has led to the hope that these agents may improve outcomes in a range of different treatment indications and in early as well as late stage NSCLC. 


\section{The potential of Radiotherapy with immunotherapy combinations.}

Despite the excitement of durable remissions seen in the three key studies of using immune checkpoint inhibitors in lung cancer, the response rates were low (18-20\%) with only a minority of patients achieving a response [15-17]. The key focus in radiobiology over the last decades has been the mechanism of radiotherapy-induced tumour cell death and research on radiation induced damage to cell structures mediated by free-radicals, leading to the production of DNA double-strand breaks, which in turn lead to apoptosis, if not repaired [18-20]. However as our understanding of the effects of RT has increased it has been recognised that radiation has effects on the vascular system, the tumour stroma and the host immune response. The impact that RT is known to have on the generation of tumour-specific immunity, includes enhanced antigen release, expression of NK2GD ligands, complement deposition, production of type I IFN, Increased major histocompatibility complex (MHC) and neo-antigen expression and the induction of immunogenic cell death [21-25]. Other elements of immunogenic modulation include changes in the mechanism of antigen presentation and translocation of calreticulin to the cell surface [26-27]. Thus RT may act as a primer for or stimulus to initiate or augment an immune mediated anti-tumour response.

Despite the ability of RT to induce local immune responses, the generation of systemic anti-tumour immunity that leads to clinical responses outside of the irradiated tumour area (the abscopal effect) is rare in clinical practice [28]. This lack of abscopal effects is thought to be secondary to the nature of the immuno-suppressive tumour microenvironment outlined above. Numerous preclinical studies have however confirmed that systemic anti-tumour immune responses can be generated using RT and immunomodulatory agents [7].

Recently there has been increasing interest in the translation of these findings to the clinic which has been fuelled by a number of provocative case reports and Phase II studies [29-32]. Overall these results suggest RT after immunoregulatory agents may lead to abscopal responses in some patients 
providing optimism that RT can enhance the systemic anti-immune response. The premise is that RT delivered to the tumour appears able to enhance anti-tumour immunity by inducing tumour antigen expression and liberating tumour antigen from dying tumour cells and thus activating anti-tumour immune responses. These local RT induced immune responses however need to be augmented with the addition of immune checkpoint inhibitors which increase enhance the local and systemic immune response by overcoming the tumour induced T-cell inhibition and immune suppression [33]. Thus combining RT with inhibitors of PD-1 or the ligand of PD-1 (PD-L1) appears to be an attractive option to enhance the effectiveness of either treatment [34]. Given the durable remissions seen with antiPD-1 / PD-L1 mAb for some patients with NSCLC and important role played by RT in the management of NSCLC it is logical to try and increase response rates and improve outcome by combination approaches. 
Table 1: Studies of Pembrolizumab or Nivolumab in combination with radiotherapy in NSCLC.

\begin{tabular}{|c|c|c|c|c|}
\hline $\begin{array}{l}\text { Study Name / } \\
\text { NCT number }\end{array}$ & Study intervention & Phase & Host institution & Status \\
\hline PEMBRO-RT ${ }^{35}$ & $\begin{array}{l}\text { Pembrolizumab after } \\
\text { SABR Versus } \\
\text { Pembrolizumab Alone in } \\
\text { Advanced NSCLC }\end{array}$ & $\begin{array}{l}\text { Randomised } \\
\text { Phase } 2\end{array}$ & $\begin{array}{c}\text { Netherlands } \\
\text { Cancer Institute, } \\
\text { Amsterdam }\end{array}$ & $\begin{array}{l}\text { Open, } \\
\text { recruiting }\end{array}$ \\
\hline NCT02444741 & $\begin{array}{l}\text { Dose escalation study of } \\
\text { Pembrolizumab and } \\
\text { SABR in stage IV NSCLC }\end{array}$ & $\begin{array}{c}\text { Phase } 1 \text { / Phase } \\
2\end{array}$ & $\begin{array}{l}\text { M.D. Anderson } \\
\text { Cancer Center, } \\
\text { Houston, Texas }\end{array}$ & $\begin{array}{l}\text { Open, } \\
\text { recruiting }\end{array}$ \\
\hline PEAR Study ${ }^{37}$ & $\begin{array}{l}\text { Pembrolizumab and } \\
\text { Palliative Radiotherapy } \\
\text { in Lung }\end{array}$ & Phase 1 & $\begin{array}{l}\text { Royal Marsden } \\
\text { Hospital, } \\
\text { London }\end{array}$ & In set-up. \\
\hline NCT02343952 38 & $\begin{array}{l}\text { Previous Study | Return } \\
\text { to List | Next Study } \\
\text { Consolidation } \\
\text { Pembrolizumab } \\
\text { Following } \\
\text { Chemoradiation in } \\
\text { Patients With } \\
\text { Inoperable/Unresectable } \\
\text { Stage III NSCLC } \\
\end{array}$ & Phase 1 & $\begin{array}{l}\text { Hoosier Cancer } \\
\text { Research } \\
\text { Network, USA }\end{array}$ & $\begin{array}{l}\text { Open, } \\
\text { recruiting }\end{array}$ \\
\hline NCT02621398 & $\begin{array}{c}\text { Pembrolizumab, } \\
\text { Paclitaxel, Carboplatin, } \\
\text { and Radiation Therapy in } \\
\text { Treating Patients With } \\
\text { Stage II-IIIB Non-Small } \\
\text { Cell Lung Cancer }\end{array}$ & Phase 1 & $\begin{array}{l}\text { Rutgers Cancer } \\
\text { Institute of New } \\
\text { Jersey and the } \\
\text { National Cancer } \\
\text { Institute (NCl) }\end{array}$ & $\begin{array}{l}\text { Open, } \\
\text { recruiting }\end{array}$ \\
\hline NCT02608385 & $\begin{array}{c}\text { Study of PD1 Blockade } \\
\text { by Pembrolizumab With } \\
\text { Stereotactic Body } \\
\text { Radiotherapy in } \\
\text { Advanced Solid Tumors }\end{array}$ & Phase 1 & $\begin{array}{l}\text { University of } \\
\text { Chicago }\end{array}$ & $\begin{array}{l}\text { Open, } \\
\text { recruiting }\end{array}$ \\
\hline NCT02407171 & $\begin{array}{c}\text { Evaluating the } \\
\text { Combination of MK- } \\
3475 \text { and Sterotactic } \\
\text { Body Radiotherapy in } \\
\text { Patients With Metastatic } \\
\text { Melanoma or NSCLC }\end{array}$ & Phase $1 / 12$ & Yale University & $\begin{array}{l}\text { Open, } \\
\text { recruiting }\end{array}$ \\
\hline $\mathrm{NICOLAS}^{42}$ & $\begin{array}{c}\text { Nlvolumab } \\
\text { COnsolidation After } \\
\text { Standard First-line } \\
\text { Chemotherapy and } \\
\text { Radiotherapy in Locally } \\
\text { Advanced Stage IIIA/B } \\
\text { NSCLC (NICOLAS) }\end{array}$ & Phase 2 & $\begin{array}{l}\text { European } \\
\text { Thoracic } \\
\text { Oncology } \\
\text { Platform }\end{array}$ & $\begin{array}{l}\text { Open, } \\
\text { recruiting }\end{array}$ \\
\hline
\end{tabular}




\section{Potential Radiotherapy and Immunotherapy Combinations in Non-Small Cell Lung Cancer.}

Advanced metastatic disease provides an opportunity to investigate whether radiotherapyimmunotherapy combinations may lead to abscopal responses [34]. However, the dose, fractionation and optimal delivery of radiotherapy such as SABR delivering large hypofractionated doses remains unclear. Radiotherapy doses from 2 Gy but up to 20 Gy may be sufficient to trigger an immune mediated cell death and large doses may increase the tumour cell kill and subsequent local immune response [21]. Furthermore, it is not known what effect the nature of the type of radiotherapy delivery or the particle used has on this interaction (e.g. open field radiotherapy versus intensity modulated radiotherapy or protons versus photons) and whether radiobiological effectiveness correlates to an increased tumour immune targeting in combination with checkpoint inhibitors.

The ablative and highly targeted doses of stereotactic ablative radiotherapy (SABR) in combination with checkpoint inhibitors are highly attractive given the increased radiation induced inflammation seen with SABR and the reduced surrounding normal tissue toxicity. Key to any success of an immunotherapy and radiotherapy combination is the optimal scheduling of delivery of an immunomodulating agent with SABR. Recent preclinical data addressing scheduling has suggested that the anti-PD1 mAb must be given before and during the RT, but not after RT, to bring about long term tumour clearance [33]. Therefore administering the checkpoint inhibitor prior to the commencement of radiotherapy would appear to be a reasonable approach. Furthermore, the optimal duration of checkpoint inhibition following radiotherapy is not known, but it is likely that a minimum of 1-2 months will be necessary after completion of radiotherapy. Other potential areas of investigation the use of adjuvant immune modulation after the delivery of curative intent radiotherapy or chemoradiotherapy. If shown to be safe in combination with SABR or other radiotherapy delivery modalities perhaps adding immunotherapy to concurrent chemotherapy in stage III disease may be a consideration. Given the large RT fields generally used for stage III disease, this type of combination does however need to be approached with caution given the concerns about 
increased pulmonary toxicity from such combinations. Table 1 lists clinical studies of either Nivolumab or Pembrolizumab in combination with radiotherapy in the treatment of NSCLC listed on the Clinical Trials website [35-42].

\section{Toxicity Considerations.}

One of ongoing concerns regarding immune checkpoint blockage is the risk of initiating autoimmune disease and in particular pneumonitis for lung cancer patients. Herbst et al report any grade pneumonitis rate of $4 \%$ and a grade 3 to grade 5 pneumonitis rate of $2 \%$ in those who received $10 \mathrm{mg} / \mathrm{kg}$ of Pembrolizumab [15]. Clearly delivering radiotherapy to normal tumour tissue in combination with immunotherapy may increase the risk of pneumonitis. Thus the design of potential phase 1 combination studies will need to consider this and consider more stringent dose constraints for normal lung tissue toxicity than would ordinarily be used. Other key immune mediated toxicities reported include hypo or hyperthyroidism, colitis, severe skin reactions, pancreatitis, myositis, adrenal insufficiency, hepatitis, hypophysitis and type 1 diabetes mellitus [15].

Beyond the immediate concern of immune mediated complications from such combinations described above, there is concern about delivery such radiotherapy and immunotherapy combinations in patients with advanced NSCLC, who often have multiple comorbidities precluding the use of cytotoxic systemic therapy in the first instance. In any early phase studies, when considering inclusion criteria, a judicious balance will have to be struck between ensuring safety of the study combination and the ensuring the study is representative of patients with advanced NSCLC. It is recognised that novel trial designs will need to be considered to ensure safe and efficient recruitment [43].

\section{Patient selection and stratification.}

There is currently intense investigation to investigate and develop immune biomarkers that predict the minority of patients who might benefit most from PD1-PD-L1 blockage. PD-L1 tumour expression 
has been used as an inclusion criteria for some of the mono-therapy studies in NSCLC [15]. However, any correlation between PD-L1 expression within the tumour, as measured by immunohistochemistry, has not been reproduced across the various studies and tumour subtypes. PD-1 expression of the immune effector cells populations in the tumour micro-environment is also of potential importance $[44,45]$. In the published studies of Nivolumab and Pembrolizumab in non-squamous NSCLC, there is a clear correlation between PD-1 expression and clinical response to treatment $[15,17]$. However this correlation is not seen in squamous cell NSCLC and in the recent study of Nivolumab in squamous NSCLC expression of the PD-1 ligand was neither prognostic nor predictive of benefit. [16]. Key to assessing PD-L1 expression is the method used and a recent study suggests that PD-L1 gene copy number may provide better correlation in selecting patients who are likely to respond to checkpoint inhibition [46]. However, it is not known if PD-L1 expression will correlate with clinical response in any checkpoint inhibitor and radiotherapy combination. Given the potential serious toxicities arising from the immune checkpoint inhibitors and comparatively low monotherapy response rates $(19 \%$ seen in the second-line treatment of non-squamous NSCLC), patient selection for therapy will be paramount to ensuring an optimal combination with radiotherapy in patients with lung cancer [17].

\section{Challenges in assessing response.}

The key to assessing the utility of any RT and immunotherapy combination for patients with lung cancer is the assessment of response and clinical effectiveness. A potential challenge after either SABR or immunotherapy when given as single agent therapies is progressive disease as defined by RECIST criteria which is in fact pseudo-progression and appears indicative of immune effector cell infiltration into the tumour prior to eventual tumour response [47]. Pseudo-progression following SABR in the treatment of stage 1 lung cancer may be observed for up to 1 year after treatment, even when PET/CT is used to reassess the treated area and low grade FDG uptake may remain and increase in intensity for up to 1 year after treatment [48]. In a recent study of Pembrolizumab as monotherapy in the treatment of melanoma, RECIST 1.1 under-estimated the clinical response rates in up to $15 \%$ of 
patients [49-50]. Given that overall survival may be only robust endpoint at present for studies of immunotherapy and radiotherapy, there is an urgent need to update and revise tumour response criteria to best assess the real impact of radiotherapy and immunotherapy combinations making the best use of available cross-sectional imaging, biological imaging techniques and blood based biomarkers of response [51].

\section{Conclusions.}

RT and immunotherapy combinations have an attractive underpinning complementary mechanism of action. The potential ability of radiotherapy and immunotherapy combinations to overcome tumour heterogeneity in lung cancer offers the hope of more effective and durable treatment responses. Studies are currently in set-up in the UK to investigate the combination of immunotherapy with radiotherapy in lung cancer and results from these studies are eagerly awaited. 


\section{References:}

1.) Irvine EW Jr, Moffitt OP Jr. Further studies in treatment of laryngeal papillomas with bovine wart vaccine. Cancer. 1962 Nov-Dec;15:1221-3.

2.) Pardoll, D. M. The blockade of immune checkpoints in cancer immunotherapy. Nat. Rev. Cancer 12, 252-264 (2012).

3.) Alduaij W, Illidge TM. The future of anti-CD20 monoclonal antibodies: are we making progress? Blood. 2011 Mar 17;117(11):2993-3001.

4.) Amin A, White RL Jr. High-dose interleukin-2: is it still indicated for melanoma and RCC in an era of targeted therapies? Oncology (Williston Park). 2013 Jul;27(7):680-91.

5.) Vansteenkiste J, Zielinski M, Linder A, Dahabreh J, Gonzalez EE, Malinowski W, et al. Adjuvant MAGE-A3 immunotherapy in resected non-small-cell lung cancer: phase II randomized study results. J Clin Oncol. 2013 Jul 1;31(19):2396-403.

6.) Seymour LW, Fisher KD. Oncolytic viruses: finally delivering. $\mathrm{Br} J$ Cancer. 2016 Feb 16;114(4):357-61. doi: 10.1038/bjc.2015.481.

7.) Honeychurch J, Cheadle EJ, Dovedi SJ, Illidge TM. Immuno-regulatory antibodies for the treatment of cancer. Expert Opin Biol Ther. 2015 Jun;15(6):787-801.

8.) G.P. Dunn, L.J. Old, R.D. Schreiber, The immunobiology of cancer immunosurveillance and immunoediting, Immunity 21 (2004) 137-148.

9.) Apetoh L, Ghiringhelli F, Tesniere A, Obeid M, Ortiz C, Criollo A, et al . Toll-like receptor 4-dependent contribution of the immune system to anticancerchemotherapy and radiotherapy. Nat Med. 2007 Sep;13(9):1050-9.

10.) Gardai SJ, McPhillips KA, Frasch SC, Janssen WJ, Starefeldt A, Murphy-Ullrich JE, et al. Cell-surface calreticulin initiates clearance of viable or apoptotic cells through trans-activation of LRP on the phagocyte. Cell. 2005 Oct 21;123(2):321-34.

11.) T.F. Gajewski, H. Schreiber, Y.-X. Fu, Innate and adaptive immune cells in the tumor microenvironment, Nat. Immunol. 14 (2013) 1014-1022.

12.) Spranger S, Spaapen RM, Zha Y, Williams J, Meng Y, Ha TT and Gajewski TF. Up-regulation of PD-L1, IDO, and T(regs) in the melanoma tumor microenvironment is driven by CD8(+) T cells, Sci Transl Med 5 (2013) 200ra116.

13.) Chen $\mathrm{YB}, \mathrm{Mu} \mathrm{CY}$, Huang JA. Clinical significance of programmed death-1 ligand-1 expression in patients with non-small cell lung cancer: a 5-year-follow-up study. Tumori. 2012 Nov;98(6):751-5.

14.) Honeychurch J, Cheadle EJ, Dovedi SJ, Illidge TM. Immuno-regulatory antibodies for the treatment of cancer. Expert Opin Biol Ther. 2015 Jun;15(6):787-801.

15.) Herbst RS, Baas $P$, Kim DW, Felip E, Pérez-Gracia JL, Han JY, et al. Pembrolizumab versus docetaxel for previously treated, PD-L1-positive, advanced non-small-cell lung cancer (KEYNOTE-010): a randomised controlled trial. Lancet. 2015 Dec 18. pii: S0140-6736(15)01281-7.

16.) Brahmer J, Reckamp KL, Baas $P$, Crinò L, Eberhardt WE, Poddubskaya $E$, et al. Nivolumab versus Docetaxel in Advanced Squamous-Cell Non-Small-Cell Lung Cancer. N Engl J Med. 2015 Jul 9;373(2):123-35.

17.) Borghaei H, Paz-Ares L, Horn L, Spigel DR, Steins M, Ready NE, et al. Nivolumab versus Docetaxel in Advanced Nonsquamous Non-Small-Cell Lung Cancer. N Engl J Med. 2015 Oct 22;373(17):1627-39.

18.) Prise KM, Schettino G, Folkard M and Held KD. New insights on cell death from radiation exposure, Lancet Oncol. 6 (2005) 520-528.

19.) Eriksson D, Stigbrand T. Radiation-induced cell death mechanisms, Tumor Biol. 31 (2010) 363-372. 
20.) Barker HE, Paget JT, Khan AA, Harrington KJ. The tumour microenvironment after radiotherapy: mechanisms of resistance and recurrence. Nat Rev Cancer. 2015 Jul;15(7):409-25.

21.) Golden EB, Frances D, Pellicciotta I, Demaria S, Helen Barcellos-Hoff M, Formenti SC. Radiation fosters dose-dependent and chemotherapy-induced immunogenic cell death. Oncoimmunology. 2014 Apr 25;3:e28518.

22.) Lugade AA, Sorensen EW, Gerber SA, Moran JP, Frelinger JG, Lord EM. Radiation-induced IFN-gamma production within the tumor microenvironment influences antitumor immunity. J Immunol. 2008 Mar 1;180(5):3132-9.

23.) Lugade AA, Moran JP, Gerber SA, Rose RC, Frelinger JG, Lord EM. Local radiation therapy of B16 melanoma tumors increases the generation of tumor antigen-specific effector cells that traffic to the tumor. J Immunol. 2005 Jun 15;174(12):7516-23.

24.) Matsumura S, Demaria S. Up-regulation of the pro-inflammatory chemokine CXCL16 is a common response of tumor cells to ionizing radiation, Radiat. Res. 173 (2010) 418-425.

25.) Kwilas AR, Donahue RN, Bernstein $M B$, Hodge JW. In the field: exploiting the untapped potential of immunogenic modulation by radiation in combination with immunotherapy for the treatment of cancer, Front. Oncol. 2 (2012) 104.

26.) Friedman EJ. Immune modulation by ionizing radiation and its implications for cancer immunotherapy, Curr. Pharm. Des. 8 (2002) 1765-1780.

27.) Janssens S, Tschopp J. Signals from within: the DNA-damage-induced NF-[kappa]B response, Cell Death Differ. 13 (2006) 773-784.

28.) Reynders K, Illidge T, Siva S, Chang JY, De Ruysscher D. The abscopal effect of local radiotherapy: using immunotherapy to make a rare event clinically relevant. Cancer Treat Rev. 2015 Jun;41(6):503-10.

29.) Postow MA, Callahan MK, Barker CA, Yamada Y, Yuan J, Kitano S, et al. Immunologic correlates of the abscopal effect in a patient with melanoma. N Engl J Med. 2012 Mar 8;366(10):925-31.

30.) Golden EB, Demaria S, Schiff PB, Chachoua A, Formenti SC. An abscopal response to radiation and ipilimumab in a patient with metastatic non-small cell lung cancer. Cancer Immunol Res. 2013 Dec;1(6):365-72.

31.) Slovin SF, Higano CS, Hamid O, Tejwani S, Harzstark A, Alumkal JJ, et al. Ipilimumab alone or in combination with radiotherapy in metastatic castration-resistant prostate cancer: results from an open-label, multicenter phase I/II study. Ann Oncol. 2013 Jul;24(7):1813-21.

32.) Grimaldi AM, Simeone E, Giannarelli D, Muto $P$, Falivene $S$, Borzillo V, et al. Abscopal effects of radiotherapy on advanced melanoma patients who progressed after ipilimumab immunotherapy. Oncoimmunology. 2014 May 14;3:e28780.

33.) Dovedi SJ, Adlard AL, Lipowska-Bhalla G, McKenna C, Jones S, Cheadle EJ, et al. Acquired resistance to fractionated radiotherapy can be overcome by concurrent PD-L1 blockade. Cancer Res. 2014 Oct 1;74(19):5458-68.

34.) Hanna GG, Coyle VM, Prise KM. Immune modulation in advanced radiotherapies: Targeting out-of-field effects. Cancer Lett. 2015 Nov 28;368(2):246-51.

35.) Pembrolizumab After SBRT Versus Pembrolizumab Alone in Advanced NSCLC (PEMBRO-RT). Available at: https://clinicaltrials.gov/ct2/show/NCT02492568 [Last accessed 12/07/2016].

36.) MK-3475 and Hypofractionated Stereotactic Radiation Therapy in Patients With Non-Small Cell Lung Cancer (NSCLC). Available at: https://clinicaltrials.gov/ct2/show/NCT02444741 [Last accessed 12/07/2016].

37.) Pembrolizumab and Palliative Radiotherapy in Lung (PEAR) study. Available at: https://clinicaltrials.gov/ct2/show/NCT02587455 [Last accessed 12/07/2016].

38.) Consolidation Pembrolizumab Following Chemoradiation in Patients With Inoperable/Unresectable Stage III NSCLC. Available at: https://clinicaltrials.gov/ct2/show/NCT02343952 [Last accessed 12/07/2016]. 
39.) Pembrolizumab, Paclitaxel, Carboplatin, and Radiation Therapy in Treating Patients With Stage II-IIIB Non-Small Cell Lung

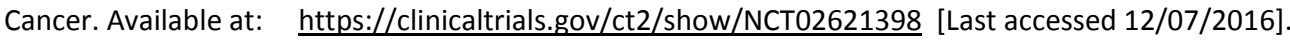

40.) Study of PD1 Blockade by Pembrolizumab With Stereotactic Body Radiotherapy in Advanced Solid Tumors. Available at: https://clinicaltrials.gov/ct2/show/NCT02608385 [Last accessed 12/07/2016].

41.) Evaluating the Combination of MK-3475 and Sterotactic Body Radiotherapy in Patients With Metastatic Melanoma or NSCLC. Available at: https://clinicaltrials.gov/ct2/show/NCT02407171 [Last accessed 12/07/2016].

42.) NIvolumab COnsolidation After Standard First-line Chemotherapy and Radiotherapy in Locally Advanced Stage IIIA/B NSCLC (NICOLAS) Available at: https://clinicaltrials.gov/ct2/show/NCT02434081 [Last accessed 12/07/2016].

43.) Faivre-Finn $C$, Snee M. Traditional phase 1 and 2 studies in thoracic radiation oncology should be abandoned. Int J Radiat Oncol Biol Phys. 2014 Nov 1;90(3):487-9.

44.) Gajewski TF, Schreiber H, Fu YX. Innate and adaptive immune cells in the tumor microenvironment. Nat Immunol. 2013 Oct;14(10):1014-22.

45.) Antonioli L, Yegutkin GG, Pacher P, Blandizzi C, Haskó G. Anti-CD73 in cancer immunotherapy: awakening new opportunities. Trends Cancer. 2016 Feb 1;2(2):95-109.

46.) Inoue $\mathrm{Y}$, Yoshimura $\mathrm{K}$, Mori $\mathrm{K}$, Kurabe $\mathrm{N}$, Kahyo $\mathrm{T}$, Mori $\mathrm{H}$, et al. Clinical significance of PD-L1 and PD-L2 copy number gains in non-small-cell lung cancer. Oncotarget. 2016 Apr 1. doi: 10.18632/oncotarget.8528. [Epub ahead of print]

47.) Chiou VL, Burotto M. Pseudoprogression and Immune-Related Response in Solid Tumors. J Clin Oncol. 2015 Nov 1;33(31):3541-3.

48.) Hoopes DJ, Tann M, Fletcher JW, Forquer JA, Lin PF, Lo SS, et al. FDG-PET and stereotactic body radiotherapy (SBRT) for stage I non-small-cell lung cancer. Lung Cancer. 2007 May;56(2):229-34.

49.) Eisenhauer EA, Therasse $P$, Bogaerts J, Schwartz $L H$, Sargent $D$, Ford R, et al. New response evaluation criteria in solid tumours: revised RECIST guideline (version 1.1). Eur J Cancer. 2009 Jan;45(2):228-47.

50.) Hodi FS, Hwu WJ, Kefford R, Weber JS, Daud A, Hamid O, et al. Evaluation of Immune-Related Response Criteria and RECIST v1.1 in Patients With Advanced Melanoma Treated With Pembrolizumab. J Clin Oncol. 2016 May 1;34(13):1510-7.

51.) Weller $A, O$ 'Brien ME, Ahmed $M$, Popat $S$, Bhosle J, McDonald F, et al. Mechanism and non-mechanism based imaging biomarkers for assessing biological response to treatment in non-small cell lung cancer. Eur J Cancer. 2016 Mar 23;59:65-78. 